\title{
0991. Nebulized heparin reduces pulmonary inflammatory responses in a rat model of acute lung injury
}

\author{
L Chimenti ${ }^{1 *}$, R Guillamat ${ }^{1}$, MN Gomez ${ }^{1}$, J Tijero ${ }^{1}$, T Lebouvier $^{2}$, L Blanch $^{1,3}$, A Artigas $^{1,3}$ \\ From ESICM LIVES 2014 \\ Barcelona, Spain. 27 September - 1 October 2014
}

\section{Introduction}

Sepsis is a mayor cause of acute lung injury (ALI). Pulmonary coagulopathy is intrinsic to ALI and in sepsis, anticoagulant system is impaired, due to consumption and downregulation by inflammatory mediators. Several studies, in ALI patients and in ALI experimental models, inconsistently suggest beneficial effects of systemic anticoagulants which affect systemic coagulation. Nebulization of anticoagulants might allow for higher pulmonary concentration and reduce the risk of systemic bleeding.

\section{Objectives}

To assess the effects of local heparin treatment in a rat model of acute lung injury.

\section{Methods}

Adult male Sprague-Dawley rats (250-300 g; n=6/group) were anesthetized with isofluorane and subjected to intratracheal administration (IA) of LPS $(10 \mu \mathrm{g} / \mathrm{g}$ b.w.). Saline or heparin $(1000 \mathrm{IU} / \mathrm{kg})$ were nebulized at 4 and $8 \mathrm{~h}$ after LPS instillation. Animals were sacrificed $24 \mathrm{~h}$ after the injury. Inflammatory cells and total proteins were assessed in bronchoalveaolar lavage fluid (BALF). IL-6, GRO- $\kappa$ C, TNF- $\alpha$ and IL-10 were measured in lung homogenate by multiplex assay (Luminex, Merck Millipore, Darmstadt, Germany). Data are reported as mean \pm SD. One-way ANOVA was used for multigroup comparisons.

\section{Results}

In BALF, nebulized heparin significantly reduced neutrophils in animals instilled with LPS $(12.4 \pm 4.3 \times 107$ cells $/ \mathrm{ml})$ compared to animals administrated with LPS and nebulized with saline $(18.1 \pm 6.1 \times 107$ cells $/ \mathrm{ml}, \mathrm{p}<0.05)$. Total BALF proteins were found to be lower in rats nebulized with heparin $(578.3 \pm 89.8 \mu \mathrm{g} / \mathrm{ml})$ than in rats treated with saline $(914.6 \pm 250.1 \mu \mathrm{g} / \mathrm{ml}, \mathrm{p}<0.005)$. In lung homogenate, IL-6, TNF- $\alpha$, GRO- $\kappa$ C levels significantly decreased in animals nebulized with heparin compared to those ones nebulized with saline (IL6: LPS+Sal: $147.7 \pm 1.3 \mathrm{ng} / \mathrm{ml}$, LPS+Hep: $47.3 \pm 20.2 \mathrm{ng} / \mathrm{ml}, \mathrm{p}<0.005$; TNF- $\alpha$ : LPS + Sal: 1.1 $\pm 0.2 \mathrm{ng} / \mathrm{ml}$, LPS + Hep: $0.3 \pm 0.1 \mathrm{ng} / \mathrm{ml}, \mathrm{p}<0.005$; GRO $-\kappa \mathrm{C}$ : LPS+Sal: $45.9 \pm 22.9 \mathrm{ng} / \mathrm{ml}$, LPS+Hep: $40.9 \pm 9.8 \mathrm{ng} / \mathrm{ml}$, $\mathrm{p}<0.005)$. IL-10 did not show any significant difference among groups.

\section{Conclusions}

Our results show that local heparin administration reduces pulmonary inflammatory responses in a rat model of acute lung injury.

\section{Grant acknowledgment}

FIS-PI12/02548, CIBERES and Fundació Parc Taulí, AGAUR GRC 532.

\section{Authors' details}

${ }^{1}$ Corporació Sanitária i Universitária Parc Taulì-UAB, Critical Care Center, Sabadell, Spain. ${ }^{2}$ Pontchaillou University Hospital, Surgical Intensive Care Unit, Rennes, France. ${ }^{3}$ CIBERES, Enfermedades Respiratorias, Bunyola, Spain.

Published: 26 September 2014

doi:10.1186/2197-425X-2-S1-P76

Cite this article as: Chimenti et al:: 0991. Nebulized heparin reduces pulmonary inflammatory responses in a rat model of acute lung injury. Intensive Care Medicine Experimental 2014 2(Suppl 1):P76. 